\title{
Use of stable isotopes of carbon to detect coconut water adulteration
}

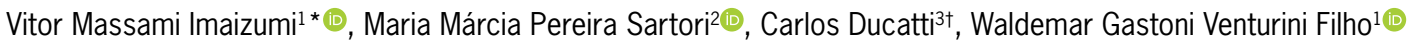

\author{
${ }^{1}$ Universidade Estadual Paulista/FCA - Depto. de Horticultura \\ - Lab. de Bebidas, R. José Barbosa de Barros, 1780 - \\ 18610-307 - Botucatu, SP - Brasil. \\ ¿Universidade Estadual Paulista/FCA - Depto. de Produção e \\ Melhoramento Vegetal. \\ 3Universidade Estadual Paulista/Instituto de Biociências - \\ Depto. de Física e Biofísica - Centro de Isótopos Estáveis, \\ R. Prof. Dr. Antônio Celso Wagner Zanin, 250 - 18618-689 \\ - Botucatu, SP - Brasil. \\ tIn memoriam \\ *Corresponding author <vtr_massami@hotmail.com>
}

Edited by: Luís Guilherme de Lima Ferreira Guido

Received August 11, 2017

Accepted January 12, 2018
ABSTRACT: Industrialized coconut water may have been adulterated by adding sugar above the limit permitted by law. According to Brazilian law, industrialized coconut water can receive the maximum addition of $1 \mathrm{~g}$ of sugar per $100 \mathrm{~mL}$ of the drink. This work aimed to detect adulteration in industrialized coconut water produced in Brazil and measure the relative isotopic enrichment in fresh coconut water, using the techniques of stable isotopes of carbon. Fresh coconut water samples from 13 locations, industrialized coconut water samples of 17 different brands and cane sugar were analyzed by Isotope Ratio Mass Spectrometer coupled to an elemental analyzer. The relative isotopic enrichment found for fresh coconut water samples ranged from -26.40 to -23.76 . From 17 brands of coconut water analyzed, 11 were adulterated by excess sugar and two were already adulterated by presenting soluble solids content higher above the threshold permitted by law. In $65 \%$ of Brazilian industrialized coconut water, the amount of exogenous sugar is higher than the limit permitted by law. Most Brazilian companies do not respect the legal limit of adding cane sugar established by law.

Keywords: Cocus nucifera L., beverage, isotope analysis, law, fraud

\section{Introduction}

The Brazilian law allows for coconut water the addition of the limit of $1 \mathrm{~g}$ of sugar per $100 \mathrm{~mL}$ of industrialized coconut water to sweeten the final product and establishes a range for soluble solids content $\left({ }^{\circ} \mathrm{Brix}\right)$ from 4.5 to 6.7 (MAPA, 2009a).

Prices of raw materials (juices, concentrates) show seasonal differences, in some cases especially materials with certain properties, e.g., sweet or acidic products. This justifies the addition of industrially produced components, e.g., sugars or acids.

The partial substitution of orange juice concentrate by much cheaper liquid sugars (beet or cane medium invert sugar or mixtures of both) or the preparation of a single strong juice from concentrate (without proper labeling) could result in a remarkable cost advantage (Rossmann, 2001).

Isotope ratio mass spectrometry (IRMS) is a promising tool to investigate food origin; thus, ${ }^{13} \mathrm{C} /{ }^{12} \mathrm{C},{ }^{18} \mathrm{O} /{ }^{16} \mathrm{O}$ and ${ }^{2} \mathrm{H} /{ }^{1} \mathrm{H}$ measurements are highly used in forensic studies to prove product authenticity. This application has been particularly useful in food quality control, as it allows detecting sugar and water added in fruit juices and tracing the geographical origin of food (Magdas and Puscas, 2011).

Plants can be classified according to their photosynthetic cycle $\mathrm{C}_{3}$ and $\mathrm{C}_{4}$. Photosynthetic cycle $\mathrm{C}_{3}$ plants form 3-carbon acid in the capture of atmospheric $\mathrm{CO}_{2}$ for photosynthesis, reducing $\mathrm{CO}_{2}$ for phosphoglycerate with the aid of RuBP carboxylase enzyme. This enzyme discriminates ${ }^{13} \mathrm{CO}_{2}$, resulting in isotopic enrichment values $\left(\delta^{13} \mathrm{C}\right)$ relatively low (average $-27 \%$ (per thousand)|. Photosynthetic cycle $\mathrm{C}_{4}$ plants form 4- carbon acid in the reduction of $\mathrm{CO}_{2}$ to aspartic acid or malic acid with the aid of the PEP carboxylase enzyme. Thus,
$\mathrm{C}_{4}$ plants have $\delta^{13} \mathrm{C}$ relatively high values (average -13 \%) (Voznesenskaya et al., 2010).

This difference of photosynthetic cycles makes the isotopic value of derivatives similar to those of the source material (Jahren et al., 2006). The use of IRMS technique has proven very effective in detecting drink adulteration, because it allows identifying the botanical origin of carbon and measuring the amount of each source $\left(\mathrm{C}_{3}\right.$ and $\left.\mathrm{C}_{4}\right)$ in beverages (Magdas et al., 2012).

This study aimed to detect adulteration in the Brazilian industrialized coconut water by adding cane sugar above the legal limit, using the stable isotopes technique.

\section{Materials and Methods}

\section{Isotope analyses}

All samples and raw materials were analyzed by Isotope Ratio Mass Spectrometer (IRMS) coupled to an elementary analyzer, using tin capsules.

\section{Isotopic enrichment of carbon}

The value of relative isotopic enrichment of carbon $\left(\delta^{13} \mathrm{C}\right)$ was calculated by the ratio ${ }^{13} \mathrm{C} /{ }^{12} \mathrm{C}$ of sample related to the international standard V-PDB /ViennaPDB). The $\delta^{13} \mathrm{C}$ of the sample is mathematically defined by equation 1 . The value of $\delta^{13} \mathrm{C}$ of coconut water samples were determined by IRMS.

$\delta^{13} \mathrm{C}$ (Sample, $\left.V-P D B\right)=\left(\frac{R_{\text {sample }}-R_{\text {standard }}}{R_{\text {standard }}}\right)$

where: $\delta^{13} \mathrm{C}=$ relative isotopic enrichment of carbon-13 of the sample related to international V-PDB standard - dimensionless; $R_{\text {sample }}=$ isotopic ratio of sample - dimensionless; $R_{\text {standard }}=$ isotopic ratio of V-PDB standard - dimensionless. 


\section{Isotope analysis of fresh coconut water}

Coconuts from 13 different locations in Brazil were acquired, two fruits from each location. The coconut water was extracted by pedicle ("coconut eye"), bottled in plastic containers and frozen from -15 to $-18{ }^{\circ} \mathrm{C}$.

\section{Isotope analysis of cane sugar}

Three types of cane sugar were analyzed in this research: crystal, refined and extra fine. Brazilian food industries normally use these types of cane sugar for their low price and availability in the market. Crystal sugar was ground in a cryogenic mill with liquid nitrogen during $3 \mathrm{~min}$ to obtain a homogeneous material with fine texture $(\leq 65 \mu \mathrm{m})$.

\section{Development of legality curve}

The Brazilian law (MAPA, 2009b) establishes that coconut water may receive the maximum amount of sugar of $1 \mathrm{~g} 100 \mathrm{~mL}^{-1}$. This information allowed to calculate the percentage of $\mathrm{C}_{3}$ carbon source depending on soluble solid content of beverages, according to equations 2 and 3. The legality curve is represented in a Cartesian graph (Figure 1), where soluble solids contents are located in axis $\mathrm{x}$ and percentage of theoretical values of $\mathrm{C}_{3}$ carbon source in axis $\mathrm{y}$.

The percentage of theoretical $\mathrm{C}_{3}$ carbon was calculated based on beverages soluble solids content, by equations 2 and 3 (Figueira, 2013).
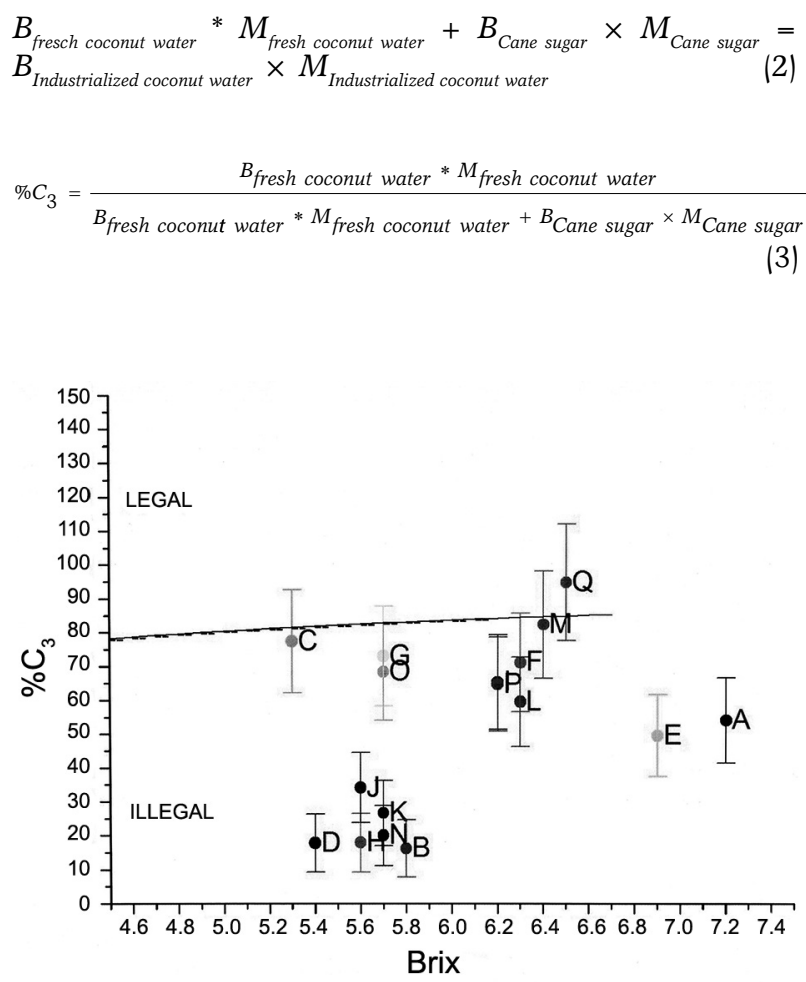

Figure 1 - Legality curve for industrialized coconut water - the theoretical minimum percentage allowed by Brazilian law is shown by the line. where: $B={ }^{\circ}$ Brix; $M=$ mass $(\mathrm{g}) ; \% \mathrm{C}_{3}=$ percentage of carbon from photosynthetic cycle $\mathrm{C}_{3}$ based on beverage soluble solids content.

Equations 2 and 3 are composed by parameters in grams $(\mathrm{g})$ dimension. The dimension milliliter $(\mathrm{mL})$ was transformed to grams using the corresponding density of

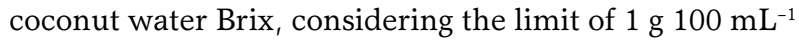
established by the Brazilian law.

\section{Isotope analysis of industrialized coconut water}

Coconut waters from 17 different brands in Brazil were analyzed in this work. Three samples of each brand was acquired, with the same volume and manufacturing batch. Two samples of each brand were used for isotope analysis and the third sample was kept frozen as rebuttal evidence. The packages were opened and the beverage was bottled in plastic containers and frozen from -15 to $-18^{\circ} \mathrm{C}$.

\section{Determination of adulteration in industrialized coconut water}

The percentage of carbon $\mathrm{C}_{3}$ source was calculated by equations 4 and 5 , using the values of $\delta^{13} \mathrm{C}$ from industrialized coconut water.

Since the final product (industrialized coconut water) is composed by two isotopically different sources (fresh coconut water $-\mathrm{C}_{3}$ source and sugarcane $-\mathrm{C}_{4}$ source), stable isotopes of carbon were used $\left({ }^{13} \mathrm{C}\right)$ to quantify the contribution of each source in the final product.

Both raw materials (coconut water and sugar) show natural variation in the value of isotopic enrichment, due to the geographical location where the plant was harvested. Thus, as the origin of raw materials used by the coconut water industry is unknown, natural variations of isotopic enrichment in the country must be considered.

The use of maximum and minimum values of isotopic enrichment found in samples of fresh coconut water (Table 1) and cane sugar (Table 2) allowed to calculate the possible maximum and minimum limits for the industrialized sample, using equations 4 and 5 .

$$
\begin{aligned}
& \delta a^{*} A+\delta b^{*} B=\delta p \\
& A+B=1
\end{aligned}
$$

where: $\delta \mathrm{a}=$ relative isotopic enrichment of carbon $\mathrm{C}_{3}$ source (fresh coconut water) $-\% 0 ; \delta b=$ relative isotopic enrichment of carbon $\mathrm{C}_{4}$ source (cane sugar) $-\% 0 ; \delta \mathrm{p}=$ relative isotopic enrichment of product (sweetened coconut water) - \%0; $\mathrm{A}=$ proportion of $\mathrm{C}_{3}$ source in the product - dimensionless; $\mathrm{B}=$ proportion of $\mathrm{C}_{4}$ source in the product - dimensionless.

This calculated range of maximum and minimum limits is represented in Figure 1 as bars and the midpoint is the mean between these two limits. Therefore, the results are not only a single point, but also a range 
Table 1 - Average and standard deviation of relative isotopic enrichment of carbon of fresh coconut water samples according to harvest location.

\begin{tabular}{|c|c|}
\hline Location (Coordinates) & $\delta^{13} \mathrm{C} * 10^{3}(\% 0)$ \\
\hline 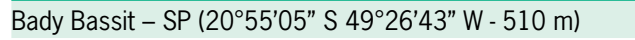 & $-23.76 \pm 0.04 c$ \\
\hline Marília - SP (22¹2’50" S 4956’45” W - 679 m) & $-23.82 \pm 0.06 c$ \\
\hline Botucatu - SP $\left(22^{\circ} 53^{\prime} 09^{\prime \prime}\right.$ S $48^{\circ} 26^{\prime} 42^{\prime \prime}$ W - $\left.840 \mathrm{~m}\right)$ & $-24.47 \pm 0.05 b c$ \\
\hline São G. da Palha - ES (1901'01" S 40³2'09" W - 200 m) & $-25.69 \pm 0.07 b c$ \\
\hline 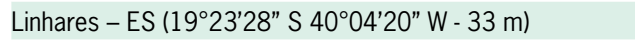 & $-25.47 \pm 0.10 b c$ \\
\hline Nova Venécia - ES (1842’38" S 40²4'02" W - 65 m) & $-25.56 \pm 0.02 b c$ \\
\hline Santa M. Eterna - BA (1551'47" S 3948" W - 122 m) & $-26.11 \pm 0.16 b c$ \\
\hline Juazeiro - BA (09²4' 50" S 40³0' 10” W - $1100 \mathrm{~m})$ & $-26.22 \pm 0.03 b c$ \\
\hline Rodelas - BA (0851' 03" S 3845' 21” W - 309 m) & $-25.49 \pm 0.07 b c$ \\
\hline Aracaju - SE (1054' 36" S 3704'12" W - 4 m) & $-24.70 \pm 0.19 b c$ \\
\hline Neópolis - SE (10¹9'12" S 36³4'46" W - 30 m) & $-26.40 \pm 0.12 a b$ \\
\hline Maceió -AL $\left(09^{\circ} 39^{\prime} 57^{\prime \prime}\right.$ S 3544’06" W - 7 m) & $-26.18 \pm 0.05 b c$ \\
\hline Sousa - PB $\left(06^{\circ} 45^{\prime} 39^{\prime \prime} \mathrm{S} 38^{\circ} 13^{\prime} 51^{\prime \prime} \mathrm{W}\right.$ - $\left.220 \mathrm{~m}\right)$ & $-23.89 \pm 0.14 c$ \\
\hline
\end{tabular}

$\delta^{13} \mathrm{C}=$ Relative isotopic enrichment of carbon of samples (\%o); Means followed by the same letters in the row do not differ by the Tukey test $(p<0.05)$.

Table 2 - High and low values of relative isotopic enrichment of carbon of sugar samples.

\begin{tabular}{lccc}
\hline Type & Number of brands & Average \pm standard deviation $\delta^{13} C^{*} 10^{3}$ & High/Low $\delta^{13} C^{*} 10^{3}$ \\
\hline Extra fine & 2 & $-14.16 \pm 0.05$ & $-14.28 /-14.03$ \\
Refined & 3 & $-14.24 \pm 0.16$ & $-14.48 /-13.84$ \\
Crystal & 9 & $-14.21 \pm 0.11$ & $-14.79 /-13.82$ \\
Overall Average & - & $-14.20 \pm 0.11$ & - \\
\hline
\end{tabular}

$\delta^{13} \mathrm{C}=$ Relative isotopic enrichment of carbon of sugar $(\%)$.

of possibilities that consider all natural variations of the sources. Both legality curve and range (Figure 1) present values of $\% \mathrm{C}_{3}$. Beverages were considered legal, when their values (midpoints) were above the legality curve. Beverages were considered adulterated, when their values were below the legality curve. Coconut water brands were considered legal, when their midpoints were below the legality curve, but with bars touching it.

\section{Statistical analysis}

The data in this research were submitted to analysis of variance and means were compared by the Tukey test and considered significant when $p<0.05$.

\section{Results and Discussion}

\section{Soluble solids analysis}

Brands $\mathrm{A}$ and $\mathrm{E}$ had soluble solids content higher than the threshold established by law (4.5 to $\left.6.7^{\circ} \mathrm{Brix}\right)$, indicating non-compliance with the Brazilian law in this parameter. The remaining samples showed with soluble solid values within the range established by law.

\section{Isotope analysis of fresh coconut water and sugar}

\section{Fresh coconut water}

The relative isotopic enrichment values of fresh coconut water are shown in Table 1. Despite the geographical distance between São Paulo and Paraíba States, $\delta^{13} \mathrm{C}$ values do not differ, probably due to several conditions where the coconut was harvest (soil, climate, water). Although the results in this research indicate no relationship between ${ }^{13} \mathrm{C}$ values and latitude of harvesting, this subject needs to be further analyzed to create a Brazilian database for $\delta^{13} \mathrm{C}$ of coconut water and investigate the reasons for such variations.

\section{Sugar}

The data presented in Table 2 shows variations in $\delta^{13} \mathrm{C}$ values of commercial sugar analyzed in this work. Higher variation was found in crystal sugar (from -14.79 $\%$ to $-13.82 \%$ ) , probably because the number of samples was higher for this type of sugar.

Other authors have published isotope values of cane sugar (refined and crystal). Banerjee et al. (2015) and Figueira et al. (2013) found values from -12.50\%0 to $-11.90 \%$ and $-13.06 \%$ to $-12.51 \%$, respectively, and Jahren et al. (2006), from $-12.71 \%$ to $-11.59 \%$. Due to its influence on results, this high variation (3\%) must be considered in the calculation of results.

\section{Development of legality curve}

Table 3 presents the data used to calculate the theoretical values of $\% \mathrm{C}_{3}$ for legality curve. Each value of the right column $\left(\% \mathrm{C}_{3}\right)$ indicates the legal limit according to their Brix value of the theoretical drink sweetened using $1 \mathrm{~g}$ of cane sugar per amount of final product in mass (corresponding to $100 \mathrm{~mL}$ ).

The legality curve was set up from 4.5 to $6.7^{\circ} \mathrm{Brix}$, in compliance with the law. If sample $\% \mathrm{C}_{3}$ is lower than $4.5^{\circ}$ Brix or higher than $6.7^{\circ} \mathrm{Brix}$, it is already adulterated. No sample was found below $4.5^{\circ}$ Brix in this research. 
Table 3 - Calculation of percentage of theoretical $C_{3}$ source of industrialized coconut water.

\begin{tabular}{lccc}
\hline $\begin{array}{l}\text { Brix of fresh } \\
\text { coconut water }\end{array}$ & Cane sugar* & $\begin{array}{c}\text { Brix of industrialized coconut } \\
\text { water* }\end{array}$ & $\%^{*}{ }^{* *}$ \\
\hline 3.6 & 1 & 4.5 & 78 \\
3.7 & 1 & 4.6 & 79 \\
3.8 & 1 & 4.7 & 79 \\
3.9 & 1 & 4.8 & 79 \\
4.0 & 1 & 4.9 & 80 \\
4.1 & 1 & 5.0 & 80 \\
4.2 & 1 & 5.1 & 81 \\
4.3 & 1 & 5.2 & 81 \\
4.4 & 1 & 5.3 & 81 \\
4.5 & 1 & 5.4 & 82 \\
4.6 & 1 & 5.5 & 82 \\
4.7 & 1 & 5.6 & 82 \\
4.8 & 1 & 5.7 & 83 \\
4.9 & 1 & 5.8 & 83 \\
5.0 & 1 & 5.9 & 83 \\
5.1 & 1 & 6.0 & 84 \\
5.2 & 1 & 6.1 & 84 \\
5.3 & 1 & 6.2 & 84 \\
5.4 & 1 & 6.3 & 84 \\
5.5 & 1 & 6.4 & 85 \\
5.6 & 1 & 6.5 & 85 \\
5.7 & 1 & 6.6 & 85 \\
5.8 & 1 & 6.7 & 85 \\
\hline${ }^{*}(g /$ corresponding mast & $(\mathrm{g})$ from multiplying $100 \mathrm{~mL}$ by each density value); \\
${ }^{*}$ theoretical. & & &
\end{tabular}

\section{Determination of adulteration in industrialized coconut water}

The relative isotopic enrichment values and concentration ranges of $\mathrm{C}_{3}$ source of industrialized coconut water are shown in Table 4.

The midpoints of these ranges were inserted into the graph faced with the legality curve (Figure 1) to determine the legality of industrialized beverages.

Column 1 of Table 4 shows the means of isotopic enrichment found in industrialized coconut water samples and column 2 displays higher and lower percentage values of the $\mathrm{C}_{3}$ source range. Column 3 shows the midpoint between the two values of column 2 .

These figures show that brands B, D, H, I, J, K, L, $\mathrm{N}, \mathrm{P}$ are in the "illegal" region determined by the curve. Brands $C, F, G, M, O$ and $Q$, whose range touches the legality curve, were considered legal. Because I and $\mathrm{P}$ samples have a similar values of ${ }^{\circ}$ Brix and $\mathrm{C}_{3}$ percentages, they are superimposed on the graph, which blocks the view.

The amount of coconut water adulterated with sugar excess was approximately $65 \%$, considered high. It is recommended that Ministry of Agriculture take actions with companies that commit adulteration, intentionally or not, on their beverages to ensure better quality of products, providing obvious benefits to costumers.
Table 4 - Average and standard deviation of soluble solids contents, relative isotopic carbon enrichment of the samples, range of $\mathrm{C}_{3}$ source percentage contribution in industrialized coconut water, and midpoint of this range $(n=2)$.

\begin{tabular}{ccccc}
\hline Sample & Soluble solids ('Brix) & 1 & \multicolumn{1}{c}{2} & 3 \\
\hline A & $7.2 \pm 0.00$ & $-20.06 \pm 0.07$ & $67-41$ & 54 \\
B & $5.8 \pm 0.00$ & $-16.00 \pm 0.05$ & $24-8$ & 16 \\
C & $5.3 \pm 0.00$ & $-22.56 \pm 0.20$ & $93-62$ & 77 \\
D & $5.5 \pm 0.06$ & $-16.17 \pm 0.28$ & $26-9$ & 18 \\
E & $6.9 \pm 0.05$ & $-19.57 \pm 0.08$ & $62-37$ & 49 \\
\hline F & $5.8 \pm 0.06$ & $-21.89 \pm 0.01$ & $86-57$ & 71 \\
G & $5.7 \pm 0.00$ & $-22.09 \pm 0.07$ & $88-58$ & 73 \\
H & $5.6 \pm 0.00$ & $-16.19 \pm 0.56$ & $26-9$ & 18 \\
\hline I & $6.3 \pm 0.06$ & $-21.26 \pm 0.09$ & $79-51$ & 65 \\
J & $5.6 \pm 0.00$ & $-17.92 \pm 0.11$ & $44-24$ & 34 \\
K & $5.7 \pm 0.00$ & $-17.12 \pm 0.09$ & $36-17$ & 27 \\
L & $6.3 \pm 0.00$ & $-20.64 \pm 0.39$ & $73-46$ & 59 \\
M & $6.4 \pm 0.00$ & $-23.09 \pm 0.02$ & $98-66$ & 82 \\
\hline N & $5.7 \pm 0.00$ & $-16.41 \pm 0.15$ & $29-11$ & 20 \\
\hline D & $5.7 \pm 0.00$ & $-21.59 \pm 0.14$ & $83-54$ & 68 \\
\hline P & $6.2 \pm 0.00$ & $-21.20 \pm 0.36$ & $79-51$ & 65 \\
Q & $6.5 \pm 0.00$ & $-24.43 \pm 0.53$ & $112-78$ & 95 \\
\hline
\end{tabular}

$1=\delta^{13} \mathrm{C}^{\star} 10^{3}(\%) \pm$ Standard deviation; $2=\mathrm{C}_{3}$ source concentration range (\%); 3 = Midpoint of $\mathrm{C}_{3}$ source concentration range (\%).

\section{Conclusions}

The Brazilian companies of bottled coconut water use cane sugar for correction and standardization of drinks soluble solids content.

Samples A and E are adulterated because of the high content of soluble solids $\left(7.2^{\circ}\right.$ Brix and $6.9^{\circ} \mathrm{Brix}$, respectively) that exceed the upper limit of $6.7^{\circ}$ Brix required by law.

Eleven of the 17 analyzed brands are adulterated by excess sugar.

Most (65 \%) Brazilian companies do not respect

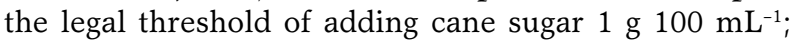
nevertheless, some companies $(35 \%)$ add sugar in compliance with current legislation.

\section{Acknowledgements}

The authors would like to thank the financial support provided by Fundação de Amparo à Pesquisa do Estado de São Paulo (FAPESP) n. 2013/10342-6.

\section{Authors' Contributions}

Conceptualization: Imaizumi, V.M., Ducatti, C., Venturini-filho, W.G. Data acquisition: Imaizumi, V.M., Ducatti, C., Venturini-filho, W.G. Data analysis: Sartori, M.M.P. Design of methodology: Ducatti, C., Venturinifilho, W.G. Writing and editing: Imaizumi, V.M., Ducatti, C., Venturini-filho, W.G., Sartori, M.M.P. 


\section{References}

Banerjee, S.; Kyser, T.K.; Vuletich, A.; Leduc, E. 2015. Elemental and stable isotopic study of sweeteners and edible oils: constraints on food authentication. Journal of Food Composition and Analysis 42: 98-116.

Figueira, R.; Venturini Filho, W.G.; Ducatti, C. 2013. Carbon isotope analysis in apple nectar beverages. Food Science and Technology 33: 32-37.

Jahren, A.H.; Saudek, C.; Yeung, E.H.; Linda Kao, W.H.; Kraft, R.A.; Caballero, B. 2006. An isotopic method for quantifying sweeteners derived from corn and sugar cane. American Journal of Clinical Nutrition 84: 1380-1384.

Magdas, D.A.; Puscas, R. 2011. Stable isotopes determination in some Romanian fruit juices. Isotopes in Environmental and Health Studies 47: 372-378.

Magdas, D.A.; Dehelean, A.; Puscas, R. 2012. Isotopic and elemental determination in some romanian apple fruit juices. The Scientific World Journal 2012: 878242

Ministério da Agricultura Pecuária e Abastecimento [MAPA]. 2009a. Decree n. 6871, 4 June 2009. Regulates Law n. 8918 of 14 July 1994, which provides the standardization, classification, registration, inspection, production and supervision of beverages $=$ Decreto n. 6871, de 4 de junho de 2009. Regulamenta a Lei n. 8918, de 14 de julho de 1994, que dispõe sobre a padronização, a classificação, o registro, a inspeção, a produção e a fiscalização de bebidas. Brasília, DF, Brazil (in Portuguese).
Ministério da Agricultura Pecuária e Abastecimento [MAPA]. 2009b. Normative Instruction n. 27 of 22 July 2009. Establishes the minimum hygienic-sanitary control procedures, identity standards and general minimum quality characteristics for coconut water $=$ Instrução Normativa n. 27, de 22 de julho de 2009. Estabelece os procedimentos mínimos de controle higiênico-sanitário, padrões de identidade e características mínimas de qualidade gerais para a água de coco. Brasília, DF, Brazil (in Portuguese).

Rossmann, A. 2001. Determination of stable isotope ratios in food analysis. Food Reviews International 17: 347-381.

Voznesenskaya, E.V.; Koteyeva, N.K.; Edwards, G.E.; Ocampo, G. 2010. Revealing diversity in structural and biochemical forms of $\mathrm{C} 4$ photosynthesis and a C3-C4 intermediate in genus Portulaca L. (Portulacaceae). Journal of Experimental Botany 61: 647-3662. 